\title{
Evaluation of the functionality of bread loaves prepared with quinoa flakes through biological tests
}

\author{
Márcia Flach Gewehr, Carlos Henrique Pagno, Daiane Danelli, Lívia Marchi de Melo, Simone \\ Hickmann Flôres*, Erna Vogt de Jong ${ }^{\dagger}$
}

Instituto de Ciência e Tecnologia de Alimentos, Universidade Federal do Rio Grande do Sul, Porto Alegre, RS, Brazil

The aim of this study was to evaluate quinoa flakes and bread prepared with the pseudocereal with regard to nutritional aspects by determining chemical composition, content of tocopherols and fatty acid composition as well as to possible beneficial effects in Wistar rats given commercial feed supplemented or not with quinoa flakes and cholesterol. The following parameters were determined: weight gain, food intake, liver weight, fat in liver and lipid profile in blood and liver. The results showed that processing affected the nutritional characteristics of bread because there was a significant increase in dietary fiber content but reduction in soluble fiber. Increased fiber did not influence food intake or weight gain. Regarding fat in liver of rats, the group that consumed bread without quinoa but with cholesterol showed higher lipid content. The addition of quinoa increased significantly the level of all types of tocopherols, especially in the group of animals that consumed $20 \%$ quinoa bread, improving the lipid profile both in blood and liver, largely due to a reduction in oxidized LDL.

Uniterms: Quinoa flakes/nutritional evaluation. Quinoa flakes/beneficial effects. Composition. Bread/ processing/effects. Bread/ nutritional evaluation. Tocopherols.

O objetivo deste estudo foi avaliar os flocos de quinoa e os pães elaborados com o pseudocereal, tanto em relação a aspectos nutricionais por meio da análise da composição centesimal, do teor de tocoferóis, composição em ácidos graxos, quanto aos possíveis efeitos benéficos, através de experimento com ratos Wistar, consumindo ração comercial, suplementados ou não com flocos de quinoa e colesterol. Foram determinados: ganho de peso, consumo de alimento, peso e gordura do fígado e perfil lipídico do sangue e do fígado. Pelos resultados, verificou-se que o processamento afetou as características nutricionais dos pães, pois houve aumento significativo no teor de fibras totais, porém redução nas fibras solúveis. O aumento de fibras não influenciou no consumo alimentar nem no ganho de peso. Em relação à gordura do fígado dos ratos, o grupo que consumiu pão sem quinoa com colesterol apresentou maior teor de lipídios. A adição de quinoa incrementou significativamente o teor de alguns tipos de tocoferóis, principalmente no grupo de animais que consumiu o pão com $20 \%$ de quinoa, melhorando o perfil lipídico, tanto do sangue quanto do fígado, principalmente devido à redução do LDLoxidado.

Unitermos: Quinoa/flocos/avaliação nutricional. Quinoa/flocos/efeitos benéficos. Pão/processamento/ efeitos. Pão/avaliação nutricional. Pão/adição de quinoa/avaliação nutricional. Tocoferóis.

*Correspondence: S. H. Flores. Instituto de Ciência e Tecnologia de Alimentos. Universidade Federal do Rio Grande do Sul. Caixa Postal 15090 - 91501-970

- Porto Alegre - RS, Brazil. E-mail: simone.flores@ufrgs.br 


\section{INTRODUCTION}

Whole grains have been the focus of scientific research and commercial research in recent years due to the results of epidemiological studies showing the protective effect of cereals against the risk of many chronic diseases. This evidence suggests that cereals and cereal products contain notable levels of bioactive compounds related to health benefits (Tiwari, Cummins, 2009; Pojic et al., 2015; Nasir et al., 2015).

Quinoa, an Andean pseudocereal, is a good source of minerals, vitamins and natural antioxidants such as vitamin $\mathrm{E}$, and has a good quality and quantity of protein (Bhargava, Shukla, Ohri, 2006; Nasir et al., 2015), fiber, and lipids, especially fatty acids (Alvarez-Jubete et al., 2010). Bread, beyond its appetizing appearance, has important nutritional value, since it can be a source of carbohydrates, protein, vitamins and minerals (Poinot et al., 2010). It is one of the most consumed foods in the human diet, where it is on the table of different peoples and social classes.

Improving the nutritional profile of white bread is a very interesting idea. Generally, wheat flour is supplemented with flour from other sources, which can enhance the content of minerals, vitamins, protein and dietary fiber (Skrbic et al., 2009). Thus, it is feasible to make bread products with quinoa added to make them healthier food, depending on the nutritional characteristics of the pseudocereal. We carried out a biological evaluation of bread loaves with different concentrations of quinoa added to determine the functionality of the products obtained. The claim of functional property must be based on scientific evidence from nutritional tests in animals (Brasil, 1999).

\section{MATERIAL AND METHODS}

\section{Samples of quinoa flakes and preparation of bread loaves}

Quinoa flakes (Chenopodium Quinoa Willd.), previously washed and subsequently rolled, produced in Peru, were purchased from Obst Trade Comércio Exterior Ltda, Porto Alegre - RS. The bread used in the experiment was produced in Seven Boys (baking company), Porto Alegre - RS. Bread loaves were prepared with three different concentrations of quinoa: one with no addition and the other two with replacement of 15 and $20 \%$ of wheat flour by quinoa flakes. All processing parameters were kept constant for the preparation of the products.

The base formulation of the bread samples was
$100 \%$ white wheat flour, $2.8 \%$ fresh yeast, $2.38 \%$ wheat gluten, $1.96 \%$ salt, $0.19 \%$ palm oil. $5.32 \%$ sugar, $0.39 \%$ soybean meal, 1.63\% "blend" (containing preservatives, acidulants, antioxidants and emulsifiers, prepared and provided by Seven Boys) and quinoa flakes. We used the sponge method for cooking the loaves. The sponge contained approximately half of the total amount of flour of the formulation, one third the salt, all the fat, half the water, a quarter of "blend," $55 \%$ of the gluten and 93\% of the yeast. The sponge ingredients were homogenized in a TBX Model 13 mixer for 2 minutes at the low speed and for 12 minutes at the high speed in accordance with that equipment. The final dough temperature was $23{ }^{\circ} \mathrm{C}$. The dough-sponge with the rest of the ingredients was fermented in a Model 1530 oven for 2 hours at $30^{\circ} \mathrm{C}$ and $80 \%$ relative humidity. The remaining ingredients with the fermented sponge were homogenized for 5 minutes at the low speed and for 8 minutes at the high speed to a final dough temperature of $25^{\circ} \mathrm{C}$. The low speed was important to guarantee a good first mixing of the ingredients before the high speed. Dough balls of $575 \mathrm{~g}$ were prepared and allowed to stand for 11 minutes in a crossed granulation molder (530/1BPF950072) and on the conveyor belt. The 575-g pieces of dough passed through a 282/ 1BF930094 molder and fell as rectangular shapes suitable for bread loaves. They were fermented in a 410/B950072/1 APV oven for 108 minutes at $42{ }^{\circ} \mathrm{C}$ and $87 \%$ relative humidity. They were then placed in the oven at $210^{\circ} \mathrm{C}$ for 21 minutes. Afterwards, the loaves were cooled to room temperature for 70 minutes, sliced and packaged. The brand of all equipment mentioned was APV Baker (Peterborough, England).

\section{Analysis of quinoa flakes and prepared bread loaves}

\section{Proximate composition}

All analyses were done in triplicate at the Laboratory of Food Science of ICTA/UFRGS, and the values given as means and standard deviation. The moisture (method 920.151), ash (method 940.26), protein ( $\mathrm{N}$ x 6.25) (968.20) and lipid contents $(962.20)$ were determined according to published methods (AOAC, 1997). The total dietary fiber (TDF) and insoluble dietary fiber (IDF) were expressed as $\mathrm{g} \cdot 100^{-1} \mathrm{~g} \mathrm{dw}$. The soluble dietary fiber (SDF) was calculated by subtracting the IDF from the TDF (AOAC, 1997) Total carbohydrate was determined by the difference (Brasil, 2003).

\section{Fatty acid composition}

The lipid profile was determined in triplicate at 
CEPPA, Federal University of Paraná according to the method described in Firestone (1998): iodine level (Method Id-87), saponification level (IF-96), and fatty acid composition (Method Ce IF-96). Preparation of fatty acid methyl esters (FAMEs) from silages was performed according to Hartman and Lago (1973) and Horwitz method (AOAC, 2000). Quality values were determined using the free fatty acids method (Method 5a-40, AOAC, 1998) and peroxide level (Method cd 8-53, AOAC, 1998). Quantification was carried out by normalization and transformation of the area percentage to $\mathrm{mg}$ per $100 \mathrm{~g}$ of edible portion, using the lipid conversion factor of Holland et al. (1991).

\section{Concentration of tocopherol}

Quantification of tocopherols ( $\alpha-, \beta-, \gamma-$, and $\delta$-tocopherol) was performed in triplicate at the Center for Analytical Quality (CQA, São Paulo, Brazil), according to the method of AOAC (2005), which consists in the saponification of liposoluble vitamins and high performance liquid chromatography (HPLC) analysis. HPLC was performed with SHIMADZU equipment consisting of LC-10ATVP solvent mixing module, FCV-10ALVP degasser, SCL-10A VP control system, CTO-10ASVP column oven and SIL-10AF autosampler. The separation was performed on an analytical reversed-phase column, Shim-Pak CLC-ODS column (3.9 mm x $150 \mathrm{~mm} \times 4 \mathrm{~mm}$ ) and monitoring was with an RF-10AXL fluorescence detector. Data were acquired and processed using the software Class-V.

\section{Statistical analysis}

Statistical analysis was performed for proximate composition, fatty acid composition, concentration of tocopherol of breads using ANOVA and when there was a significant difference between the means, the Tukey test was applied $(\mathrm{p} \leq 0.05)$.

\section{Biological evaluation}

For the biological tests, 36 adult Wistar rats weighing around $200 \mathrm{~g}$, were randomly divided into six groups of six animals each. The number of experimental animals required was determined for each group so that a $20 \%$ difference between a treatment and the standard could be found and considered significant with $95 \%$ confidence (Berndtson, 1991). Rats were placed in individual cages at room temperature of $22 \pm 2^{\circ} \mathrm{C}$ with a 12-hour light/dark cycle for 42 days. All groups were fed NUVITAL pelleted feed (complete for rats and mice) and water ad libitum. The diet and its supplements are shown in Table I.

Supplementation for groups that consumed bread was equivalent to $100 \mathrm{~g}$ (four slices), the average amount consumed daily by an adult man. The amount of cholesterol (Empresa Vetec - São Paulo) offered was about 100 times higher than the daily intake of dietary cholesterol required. All breads were ground to homogenize the crust and crumb of them and offered $(0.26 \mathrm{~g})$ together with $10 \mathrm{~g}$ of ground feed and in accordance with the group added powdered cholesterol. After the animals consumed this mixture, the pelleted feed was offered again. Weight and food intake of the experimental animals were checked every three days; these data allowed us to calculate weight gain, feed intake and feed efficiency ratio (FER) (Sgarbieri, 1987).

On the last day of the experiment, the animals were sedated with benzodiazepine $\left(0.25 \mathrm{mg} .100 \mathrm{~g}^{-1}\right.$ body weight) and anesthetized with sodium pentobarbital (4.6 mg. $100 \mathrm{~g}-{ }^{1}$ body weight). After sedation, an incision was made in the linea alba, along all the ventral part, and the liver was removed, weighed and frozen for later extraction of fat by the method described by Bligh and Dyer (1959). Total cholesterol, HDL cholesterol and triglycerides were determined using Labtest kits and oxidized LDL kit from Sigma-Aldrich. LDL cholesterol was calculated according to Friedewald, Levy, Fredrickson (1972). Liver weight was related to the weight of the rat.

TABLE I - Groups on diet supplemented with bread (GP), bread plus cholesterol (GPC), bread with 15\% quinoa plus cholesterol (GP15C), bread with 20\% quinoa plus cholesterol (GP20C), and cholesterol (GC)

\begin{tabular}{lccccc}
\hline Group & Feed & $\begin{array}{c}\text { Bread without } \\
\text { quinoa (g) }\end{array}$ & $\begin{array}{c}\text { Bread with } \\
\mathbf{1 5 \%} \text { quinoa }\end{array}$ & $\begin{array}{c}\text { Bread with } \\
\mathbf{2 0 \%} \text { quinoa }\end{array}$ & Cholesterol (g) \\
\hline GP & Nuvital & 0.26 & - & - & - \\
GPC & Nuvital & 0.26 & - & - & 0.1 \\
GP15C & Nuvital & - & 0.26 & - & 0.1 \\
GP20C & Nuvital & - & - & 0.26 & 0.1 \\
GC & Nuvital & - & - & - & 0.1 \\
\hline
\end{tabular}


The study was approved by the Research Ethics Committee of the Federal University of Rio Grande do Sul, since it was in accordance with Resolution 196/96 and the guidelines of the Brazilian Health Council.

\section{Statistical Analysis of Biological Evaluation}

The experimental design was completely randomized in a two by two factorial design as described by Bender, Doiglas, Kramer (1982). The results were expressed as mean and standard deviation for each experimental group. Statistical analysis was performed using ANOVA and when there was a significant difference between the means, the Tukey test was applied $(\mathrm{p} \leq 0.05)$.

\section{RESULTS AND DISCUSSION}

\section{Chemical characterization of quinoa flakes and bread}

Table II shows that there was a gradual increase in protein content of the bread with amount of quinoa added due to the high protein content of the pseudocereal flakes. This result agrees with the findings of Borges et al. (2013). Although quinoa flakes increased the fiber content of the bread (Table II), soluble fiber decreased compared to the standard bread. This is in agreement with results from the literature that mention the possible hydrolysis of soluble fiber by enzymes produced by yeast, as well as its partial destruction during baking (Abdul-Hamid, Luan, 2000).

Quinoa flakes contained $26.43 \%$ saturated fatty acids, predominantly palmitic acid, and $66.6 \%$ unsaturated fatty acids, represented by 46.72 to $19.88 \%$ monounsaturated and polyunsaturated (Table III). Linoleic, oleic and $\alpha$-linolenic fatty acids accounted for $16.8,42.63$ and $0.61 \%$ of total fatty acids, respectively.

There was a higher amount of unsaturated than saturated fatty acids in quinoa flakes. This characteristic is interesting because saturated fatty acids elevate cholesterol while unsaturated fatty acids have protective effects and may reduce blood levels of LDL and triglycerides (Santos, Aquino, 2008; Mithila, Khanum, 2015). The addition of quinoa flakes to bread influenced the increase in oleic, palmitic and stearic fatty acids. There were traces of linolenic acid, and the proportion of linoleic acid was constant, so it is possible that the wheat flour used contained similar amounts of these fatty acids as quinoa flakes. Although there was a high concentration of unsaturated fatty acids, quinoa flakes were stable due to their high amount of tocopherols, particularly $\alpha$ - and $\gamma$-tocopherol (Bhargava, Shukla, Ohri, 2006; RepoCarrasco, Espinoza, Jacobsen, 2003; Nasir et al., 2015.).

Table IV shows the amount of tocopherols in quinoa flakes and prepared bread loaves.

Tocopherols were found in the standard bread because according to Tiwari and Cummins (2009), these are present in cereals such as wheat, oats, rice, barley and rye. These authors believe that the loss of tocopherols in baking can be attributed to the incorporation of air into the batter in the mixing/kneading step but also to the heat in baking. It was observed that the amount of tocopherol in quinoa flakes was represented, since the $20 \%$ quinoa bread showed higher amounts of $\alpha$-, $\gamma$ - and $\delta$-tocopherol compared to the standard bread.

Moreover, heat-processed products have greater storage stability, probably due to inactivation of lipoxygenase, which is responsible for the oxidation of tocopherols. Thus, the breads contained higher amounts

TABLE II - Chemical composition of quinoa flakes and bread made with and without pseudocereal

\begin{tabular}{lcccc}
\hline $\begin{array}{l}\text { Chemical composition } \\
\text { (g/100 g) }\end{array}$ & Quinoa flakes & Standard (P) & P15\% & P20\% \\
\hline Moisture & $11.93 \pm 0.06$ & $36.55 \pm 0.03^{\mathrm{a}}$ & $34.58 \pm 0.04^{\mathrm{c}}$ & $35.37 \pm 0.03^{\mathrm{b}}$ \\
Carbohydrates & $60.95 \pm 0.02$ & $50.08 \pm 0.04^{\mathrm{a}}$ & $49.30 \pm 0.03^{\mathrm{b}}$ & $47.36 \pm 0.04^{\mathrm{c}}$ \\
Protein & $11.73 \pm 0.04$ & $8.46 \pm 0.05^{\mathrm{c}}$ & $10.29 \pm 0.05^{\mathrm{b}}$ & $11.25 \pm 0.05^{\mathrm{a}}$ \\
Lipíds & $4.88 \pm 0.07$ & $0.83 \pm 0.05^{\mathrm{b}}$ & $1.21 \pm 0.02^{\mathrm{a}}$ & $1.12 \pm 0.05^{\mathrm{a}}$ \\
Total dietary fiber & $8.65 \pm 0.07$ & $2.15 \pm 0.03^{\mathrm{c}}$ & $2.56 \pm 0.04^{\mathrm{b}}$ & $2.74 \pm 0.03^{\mathrm{a}}$ \\
Soluble dietary fiber & $4.80 \pm 0.05$ & $1.09 \pm 0.04^{\mathrm{a}}$ & $0.75 \pm 0.04^{\mathrm{b}}$ & $1.00 \pm 0.10^{\mathrm{a}}$ \\
Insoluble dietary fiber & $3.85 \pm 0.04$ & $1.06 \pm 0.03^{\mathrm{b}}$ & $1.81 \pm 0.02^{\mathrm{a}}$ & $1.74 \pm 0.05^{\mathrm{a}}$ \\
Ash & $1.86 \pm 0.06$ & $1.93 \pm 0.07^{\mathrm{b}}$ & $2.06 \pm 0.12^{\mathrm{ab}}$ & $2.16 \pm 0.06^{\mathrm{a}}$ \\
\hline
\end{tabular}

Values in the same row with different letters indicate a statistically significant difference between the means by the Tukey test $(\mathrm{p} \leq 0.05)$. $(\mathrm{n}=3)$. Standard (P) bread without quinoa, P15\% bread with $15 \%$ quinoa added, P20\% bread with $20 \%$ quinoa added. 
TABLE III - Lipid composition of quinoa flakes and bread made with and without pseudocereal

\begin{tabular}{lcccc}
\hline & Quinoa flakes & Standard $\mathbf{( P )}$ & $\mathbf{P 1 5 \%}$ & P20\% \\
\hline $\begin{array}{l}\text { Total lipids } \\
\text { (g/100 g-wet weight) }\end{array}$ & 4.88 & 0.83 & 1.21 & 1.12 \\
\hline Composition of fatty acids (g/100 g-wet weight) & & & \\
\hline Saturated & $1.29 \pm 0.06$ & $0.40 \pm 0.02^{\mathrm{b}}$ & $0.57 \pm 0.03^{\mathrm{a}}$ & $0.53 \pm 0.03^{\mathrm{a}}$ \\
Palmitic & $0.85 \pm 0,04$ & $0.32 \pm 0.02^{\mathrm{b}}$ & $0.37 \pm 0.02^{\mathrm{a}}$ & $0.37 \pm 0.02^{\mathrm{a}}$ \\
Stearic & $0.10 \pm 0.01$ & $0.07 \pm 0.01^{\mathrm{b}}$ & $0.16 \pm 0.01^{\mathrm{a}}$ & $0.13 \pm 0.01^{\mathrm{a}}$ \\
Monounsaturated & $2.28 \pm 0.11$ & $0.26 \pm 0.01^{\mathrm{b}}$ & $0.36 \pm 0.02^{\mathrm{a}}$ & $0.34 \pm 0.02^{\mathrm{a}}$ \\
Oleic & $2.08 \pm 0.10$ & $0.26 \pm 0.01^{\mathrm{b}}$ & $0.34 \pm 0.02^{\mathrm{a}}$ & $0.33 \pm 0.02^{\mathrm{a}}$ \\
Polyunsaturated & $0.97 \pm 0.05$ & $0.13 \pm 0.01^{\mathrm{a}}$ & $0.14 \pm 0.01^{\mathrm{a}}$ & $0.14 \pm 0.01^{\mathrm{a}}$ \\
Linolenic & $0.03 \pm 0.001$ & - & $0.01 \pm 0.001^{\mathrm{a}}$ & $0.01 \pm 0.001^{\mathrm{a}}$ \\
Linoleic & $0.82 \pm 0.04$ & $0.13 \pm 0.01^{\mathrm{a}}$ & $0.13 \pm 0.01^{\mathrm{a}}$ & $0.12 \pm 0.01^{\mathrm{a}}$ \\
\hline
\end{tabular}

Values in the same row with different letters indicate a statistically significant difference between the means by the Tukey test $(\mathrm{p} \leq 0.05)$. $(\mathrm{n}=3)$. Standard $(\mathrm{P})$ bread without quinoa, $\mathrm{P} 15 \%$ bread with $15 \%$ off quinoa added, $\mathrm{P} 20 \%$ breads with $20 \%$ quinoa added.

TABLE IV - Quantity and types of tocopherols found in quinoa flakes and standard and 20\% quinoa loaves

\begin{tabular}{lccc}
\hline Tocopherols (mg/100 g) & Quinoa flakes & Standard & P20\% \\
\hline$\alpha$ (Alpha) & 2.14 & $0.764 \pm 0.30^{\mathrm{b}}$ & $0.950 \pm 0.34^{\mathrm{a}}$ \\
$\beta$ (Beta) & 0.43 & $<0.08^{\mathrm{a}}$ & $<0.08^{\mathrm{a}}$ \\
$\gamma$ (Gamma) & 2.95 & $1.747 \pm 0.87^{\mathrm{b}}$ & $2.320 \pm 0.90^{\mathrm{a}}$ \\
$\delta$ (Delta) & 0.56 & $0.093 \pm 0.37^{\mathrm{b}}$ & $0.015 \pm 0.59^{\mathrm{a}}$ \\
\hline
\end{tabular}

Values in the same row with different letters indicate a statistically significant difference between the means by the Tukey test $(\mathrm{p} \leq 0.05)$. $(\mathrm{n}=3)$. Standard (P) bread without quinoa, $\mathrm{P} 20 \%$ bread with $20 \%$ quinoa added.

of $\delta$ - and $\gamma$-tocopherol (higher antioxidant power) and the desired amount of $\alpha$-tocopherol, since P20\% contained $79 \%$ of the recommended daily allowance for vitamin E $(12 \mathrm{mg})$. This type of tocopherol reduces the risk of breast and head and neck cancer, coronary disease and cardiovascular disease, while $\gamma$-tocopherol inhibits the proliferation of cancer cells and reduces heart disease (Tiwari, Cummins, 2009).

\section{Biological evaluation}

Some foodstuffs may reduce hunger and thus food intake due to the influence of some nutrients on satiety. Berti et al. (2005) reported a link between high levels of protein and/or fiber and greater satiety. Mithila and Khanum (2015) observed a reduction in food intake in their study with quinoa. The results in Table $\mathrm{V}$ indicate that there was no statistically significant difference in food intake, FER and weight gain, between the five groups. This was in line with the fact that these experimental breads were not characterized as a source of fiber, which showed less than $2.5 \mathrm{~g}$ of fiber per serving of product (Table II). In relation to protein, Takao et al. (2005) observed that the protein isolated from quinoa seeds did not affect weight gain or food intake. Furthermore, Berti et al. (2005) observed in male volunteers that bread, as well as quinoa prepared as a risotto, was not a satiating product.

None of the groups showed a statistically significant difference in aspartate aminotransferase (AST) activity, as shown in Table VI. The weight of the liver relative to body weight followed the same pattern. However, the amount of fat in this organ of the group that ingested the cholesterol and standard bread (GPC) was statistically greater than in all other groups, which did not differ one from the other, indicating an interaction between bread and cholesterol.

The results, in general, showed a certain equivalence between the GP and GC groups, since they showed no statistically significant difference in all blood parameters analyzed (Table VII). The GPC group had greater levels of oxidized LDL, triglycerides, LDL and total cholesterol and lower HDL in all treatments, suggesting an interaction between bread without added quinoa and cholesterol. 
TABLE V - Means and standard deviations of weight gain (WG), food intake (FI) and feed efficiency ratio (FER) of adult rats with and without supplementation of their diet with bread and cholesterol for 42 days

\begin{tabular}{lccc}
\hline GROUP & WG $(\mathbf{g})$ & FI $(\mathbf{g})$ & FER \\
\hline GP & $167.5 \pm 20.6^{\mathrm{a}}$ & $952.0 \pm 104.0^{\mathrm{a}}$ & $0.18 \pm 0.01^{\mathrm{a}}$ \\
GPC & $171.6 \pm 23.3^{\mathrm{a}}$ & $999.4 \pm 125.0^{\mathrm{a}}$ & $0.17 \pm 0.01^{\mathrm{a}}$ \\
GP15C & $165.6 \pm 18.3^{\mathrm{a}}$ & $945.4 \pm 94.9^{\mathrm{a}}$ & $0.18 \pm 0.01^{\mathrm{a}}$ \\
GP20C & $156.4 \pm 23.4^{\mathrm{a}}$ & $958.5 \pm 92.7^{\mathrm{a}}$ & $0.16 \pm 0.02^{\mathrm{a}}$ \\
GC & $159.8 \pm 24.9^{\mathrm{a}}$ & $932.7 \pm 89.2^{\mathrm{a}}$ & $0.17 \pm 0.01^{\mathrm{a}}$ \\
\hline
\end{tabular}

GP - diet with bread; GPC - diet with bread and cholesterol; GP15C - diet with 15\% quinoa bread and cholesterol; GP20C - diet with $20 \%$ quinoa bread and cholesterol; GC - diet with cholesterol. Values in the same column with different letters indicate a statistically significant difference between the means by the Tukey test $(\mathrm{p} \leq 0.05)$. $(\mathrm{n}=6)$

TABLE VI - Means and standard deviations of levels of aspartate aminotransferase (AST) and weight and fat content of liver of adult mice, with and without supplementation of their diet with bread and cholesterol for 42 days

\begin{tabular}{lccc}
\hline GROUP & $\begin{array}{c}\text { AST } \\
\text { (units/mL) }\end{array}$ & Weight of liver (\%) & Fat in liver (\%) \\
\hline GP & $95.69 \pm 11.15^{\mathrm{a}}$ & $3.35 \pm 0.23^{\mathrm{a}}$ & $4.08 \pm 0.84^{\mathrm{b}}$ \\
GPC & $115.97 \pm 5.54^{\mathrm{a}}$ & $3.25 \pm 0.45^{\mathrm{a}}$ & $5.22 \pm 0.51^{\mathrm{a}}$ \\
GP15C & $114.17 \pm 12.97^{\mathrm{a}}$ & $3.22 \pm 0.19^{\mathrm{a}}$ & $3.44 \pm 0.63^{\mathrm{b}}$ \\
GP20C & $109.58 \pm 11.56^{\mathrm{a}}$ & $3.12 \pm 0.25^{\mathrm{a}}$ & $3.73 \pm 0.35^{\mathrm{b}}$ \\
GC & $105.28 \pm 12.02^{\mathrm{a}}$ & $3.40 \pm 0.43^{\mathrm{a}}$ & $4.10 \pm 0.37^{\mathrm{b}}$ \\
\hline
\end{tabular}

GP - diet with bread; GPC - diet with bread and cholesterol; GP15C - diet with 15\% quinoa bread and cholesterol; GP20C - diet with $20 \%$ quinoa bread and cholesterol; GC - diet with cholesterol. Values in the same column with different letters indicate a statistically significant difference between the means by the Tukey test $(\mathrm{p} \leq 0.05)$. $(\mathrm{n}=6)$

Cardiovascular diseases are those most closely related to diet. In coronary artery disease, the formation of atherosclerotic plaques occurs through deposition of cholesterol esters and aggregation of oxidized LDL by macrophages (Mancini-Filho, 2006).

LDL is susceptible to oxidation when blood plasma levels of antioxidants are low, both endogenous and exogenous. In this oxidation process, the substrates involved include polyunsaturated fatty acids, present in the triacylglycerides that are part of the core of LDL, and cholesterol present both in the central part and periphery of LDL. Consequently, oxidized LDL accumulates on the walls of blood vessels, forming the most important components of atherosclerotic plaques (Valenzuela, Sanhueza, Nieto, 1998). According to the cited authors, the prevention of oxidation of lipids by tocopherols may occur because studies have demonstrated the efficacy of $\alpha$-tocopherol in inhibiting the formation of lipid oxides in products with polyunsaturated fatty acids, stored for some time, unlike the antioxidant butyl hydroxyanisole (BHA).

The presence of the phenolic group in tocopherols is critical for antioxidant activity due to the ability to donate a phenolic hydroxyl group from the chromanol ring to free radicals, to stabilize and stop the reaction propagation phase in the oxidative chain (Tiwari, Cummins, 2009).

The bread of the GP20C group should have had greater antioxidant capacity compared to standard bread, because it had the highest amount of tocopherol (Table IV). This result corroborates the findings in the analysis of blood oxidized LDL (Table VII).

Serum oxidized LDL levels were statistically higher in the GPC group relative to the GP15C and GP20C groups, which did not differ one from the other. Protection was probably due to tocopherols in quinoa flakes, because the lowest oxidized LDL levels were seen in the groups that consumed bread containing the pseudocereal. According to Mithila and Khanum (2015), the unsaturated fatty acids and tocopherols in pseudocereals may contribute to the reduction in LDL levels.

Fatty acids directly affect the lipid profile, where the saturated fatty acids act differently depending on the type. Palmitic acid raises serum levels of cholesterol and LDL cholesterol, while stearic acid does not raise cholesterol or LDL cholesterol (Moretto, Fett, 1998; Olivares, Zacarias, 
TABLE VII - Means and standard deviations of blood lipid parameters of adult mice with and without supplementation of their diet with bread and cholesterol for 42 days

\begin{tabular}{lccccc}
\hline GROUP & $\begin{array}{c}\text { Oxidized LDL } \\
(\mathbf{m g} / \mathbf{d L})\end{array}$ & $\begin{array}{c}\text { Triglycerídes } \\
(\mathbf{m g} / \mathbf{d L})\end{array}$ & $\begin{array}{c}\text { LDL } \\
(\mathbf{m g} / \mathbf{d L})\end{array}$ & $\begin{array}{c}\text { HDL } \\
(\mathbf{m g} / \mathbf{d L})\end{array}$ & $\begin{array}{c}\text { Cholesterol Total } \\
(\mathbf{m g} / \mathbf{d L})\end{array}$ \\
\hline GP & $85.11 \pm 8.69^{\mathrm{ab}}$ & $67.66 \pm 5.76^{\mathrm{b}}$ & $36.83 \pm 5.12^{\mathrm{a}}$ & $35.40 \pm 3.11^{\mathrm{b}}$ & $85.76 \pm 8.76^{\mathrm{ab}}$ \\
GPC & $89.69 \pm 6.90^{\mathrm{a}}$ & $90.75 \pm 4.93^{\mathrm{a}}$ & $37.88 \pm 4.03^{\mathrm{a}}$ & $34.72 \pm 2.41^{\mathrm{b}}$ & $90.24 \pm 6.91^{\mathrm{a}}$ \\
GP15C & $71.68 \pm 4.99^{\mathrm{b}}$ & $36.91 \pm 6.71^{\mathrm{c}}$ & $24.90 \pm 3.03^{\mathrm{bc}}$ & $39.96 \pm 3.29^{\mathrm{ab}}$ & $72.24 \pm 5.06^{\mathrm{bc}}$ \\
GP20C & $71.69 \pm 3.46^{\mathrm{b}}$ & $36.06 \pm 6.72^{\mathrm{c}}$ & $18.59 \pm 5.92^{\mathrm{c}}$ & $42.48 \pm 1.75^{\mathrm{a}}$ & $68.38 \pm 8.66^{\mathrm{c}}$ \\
GC & $83.76 \pm 8.84^{\mathrm{ab}}$ & $69.68 \pm 10.67^{\mathrm{b}}$ & $30.72 \pm 4.03^{\mathrm{ab}}$ & $39.65 \pm 3.54^{\mathrm{ab}}$ & $84.31 \pm 8.86^{\mathrm{abc}}$ \\
\hline
\end{tabular}

GP - diet with bread; GPC - diet with bread and cholesterol; GP15C - diet with 15\% quinoa bread and cholesterol; GP20C - diet with $20 \%$ quinoa bread and cholesterol; GC - diet with cholesterol. Values in the same column with different letters indicate a statistically significant difference between the means by the Tukey test $(\mathrm{p} \leq 0.05)$. $(\mathrm{n}=6)$.

1997). In the present study, it was found that the addition of quinoa flakes increased the levels of palmitic acid approximately $15 \%$ and stearic acid $129 \%$, compared to the amounts present in standard bread.

Statistical difference was found in the analysis of total cholesterol and LDL cholesterol between the GPC group (greater quantity) and the GP15C and GP20C groups, which showed similar levels (Table VII). The higher the level of oxidized LDL, the more fatty acids participate in the oxidation of lipids. The products of such oxidation can cause damage to the epithelium, for example, from hydroperoxides of linoleic acid oxidation, inhibiting the synthesis of prostaglandin $\mathrm{I}_{2}$. Cholesterol in the oxidized form is taken up by macrophages, but this does not occur with the unoxidized form, and oxidized LDL cholesterol is a greater promoter of monocyte aggregation (Mancini-Filho, 2006).

Although the different loaves had practically the same amount of linoleic acid, its availability was possibly higher in $20 \%$ quinoa bread followed by $15 \%$ quinoa bread and standard. Thus, the levels of total cholesterol and LDL cholesterol were lower in $20 \%$ and $15 \%$ quinoa bread, since according to Olivares and Zacarias (1997), linoleic acid moderately reduces serum levels of cholesterol and LDL cholesterol.

With regard to tocopherol levels and lipid oxidation, it was found that the GP20C group had significantly higher HDL levels relative to GPC, but did not differ from the GP15C group. This possibly occurred because oleic acid has a neutral effect on LDL cholesterol, but increases HDL slightly (Olivares, Zacarias, 1997). There was an increase in oleic acid of approximately $31 \%$ in bread with quinoa compared to standard bread (Table III).

With respect to triglyceride levels, synergism was found between the consumption of standard bread and cholesterol by rats, because the GC and GP groups did not differ statistically, but showed statistical difference when compared with the GPC group. The GP15C and GP20C groups had statistically lower levels compared to the others. Probably the addition of the pseudocereal hampered the synthesis of triglycerides, and also protected against dietary cholesterol. This could have occurred due to the presence of tocopherols, which helped somewhat to obtain the lipid profile described, along with the small amount of linolenic acid in the GP20C and GP15C groups. According to Mancini-Filho (2006), these factors inhibit the synthesis of triglycerides and secretion of VLDL (very low density lipoproteins), favoring the hepatic secretion of smaller VLDLs leading to the formation of small LDLs, which are not considered atherogenic.

The blood lipid profiles were similar to the triglyceride and total cholesterol levels in the liver (Table VIII). Both for triglycerides and total cholesterol, synergism was observed between bread and cholesterol when both were offered together in the diet, where both triglycerides and cholesterol levels were statistically higher in the GPC group compared to the other treatments.

The lipid profile showed possible protection with the treatments with bread containing quinoa compared to standard bread. The differences in LDL (25\% lower) and HDL ( $6 \%$ higher) were more pronounced for the treatment with bread with $20 \%$ replacement of wheat flour by quinoa flakes, compared to the GP $15 \mathrm{C}$ group, albeit without statistical significance (Table VII). According to Gorinstein et al. (2007), the high content and quality of protein in quinoa flakes might have had a role, albeit small, in the overall antioxidant activity, where proteins can be effective antioxidants in the inhibition of lipid peroxidation and can chelate free radicals. The $20 \%$ quinoa bread had a higher protein content (Table II) compared to $15 \%$ quinoa bread and, accordingly, perhaps higher antioxidant power. 
TABLE VIII - Means and standard deviations of liver lipid levels of adult rats, with and without supplementation of their diet with bread and cholesterol for 42 days

\begin{tabular}{lcc}
\hline GROUP & $\begin{array}{c}\text { Triglycerides } \\
(\mathbf{m g} / \mathbf{d L})\end{array}$ & $\begin{array}{c}\text { Total cholesterol } \\
(\mathbf{m g} / \mathbf{d L})\end{array}$ \\
\hline GP & $35.04 \pm 7.91^{\mathrm{b}}$ & $20.71 \pm 1.35^{\mathrm{c}}$ \\
GPC & $77.53 \pm 3.70^{\mathrm{a}}$ & $32.06 \pm 1.59^{\mathrm{a}}$ \\
GP15C & $42.94 \pm 6.24^{\mathrm{b}}$ & $21.10 \pm 2.25^{\mathrm{c}}$ \\
GP20C & $45.07 \pm 4.96^{\mathrm{b}}$ & $20.08 \pm 2.19^{\mathrm{c}}$ \\
GC & $47.84 \pm 11.06^{\mathrm{b}}$ & $26.98 \pm 3.62^{\mathrm{b}}$ \\
\hline
\end{tabular}

GP - diet with bread; GPC - diet with bread and cholesterol; GP15C - diet with 15\% quinoa bread and cholesterol; GP20C - diet with 20\% quinoa bread and cholesterol; GC - diet with cholesterol. Values in the same column with different letters indicate a statistically significant difference between the means by the Tukey test $(\mathrm{p} \leq 0.05)$. $(\mathrm{n}=6)$.

The fiber present in the bread did not directly influence the results, since the standard bread even with increased amounts of soluble fiber (Table II) showed higher levels of oxidized LDL, LDL cholesterol, total cholesterol in the blood (Table VII), indicating that probably the amount of fiber present was not sufficient to act as a functional ingredient able to reduce blood cholesterol. According to Williams (1997), Mithila, Khanum (2015), soluble fiber is fermented in the colon, producing short-chain fatty acids capable of inhibiting the synthesis of cholesterol. Probably the increase in tocopherols, by substituting $20 \%$ of wheat flour with quinoa flakes, positively influenced the lipid profile of experimental animals, where there was a decrease in oxidized LDL, LDL cholesterol, total cholesterol and triglycerides and increase in HDL in the blood and decrease in triglycerides and total cholesterol in the liver, relative to the GPC group.

\section{CONCLUSIONS}

Bread loaves prepared with the addition of quinoa had a different composition because of the quantity and variety of nutrients present in the pseudocereal. But due to the processing of the bread, there was a reduction in certain nutrients such as soluble fiber and content of tocopherols. The combined consumption of bread and cholesterol contributes to increased synthesis and deposition of fat, triglycerides and cholesterol in the liver.

The bread with $20 \%$ replacement of wheat flour by quinoa showed an increase in tocopherol content due to the balance between $\alpha$-, $\gamma$ - and $\delta$-tocopherol, improving the blood lipid profile and fat in the liver of experimental animals, in relation to the standard bread.
The results indicate the possible functionality of bread loaves with quinoa, but further studies should be conducted to confirm the efficacy of the products. Furthermore, quinoa flakes can be possibly added to foods to increase their value. However, further studies are needed to examine the processing of bread and resulting nutritional losses.

\section{ACKNOWLEDGMENTS}

We thank the Seven Boys Company for financial support and preparation of the bread samples, and UFRGS for the Scientific Initiation Scholarship. Dr. A. Leyva provided English editing of the manuscript.

\section{REFERENCES}

ABDUL-HAMID A.; LUAN Y.S. Functional properties of dietary fibre prepared from defatted rice bran. Food Chem., v.68, n.1, p.15-19, 2000.

ALVAREZ-JUBETE, L.; WIJNGAARD, H.; ARENDT, E.K.;GALLAGHER, E. Polyphenol composition and in vitro antioxidant activity of amaranth, quinoa buckwheat and wheat as affected by sprouting and baking. Food Chem., v.119, n.2, p.770-778, 2010.

ASSOCIATION OF OFFICIAL ANALYTICAL CHEMISTS. AOAC; HORWITZ, W. (ed). Official Methods of Analysis. 15. ed. Washington D.C: AOAC, 1997. v. 2.

ASSOCIATION OF OFFICIAL ANALYTICAL CHEMISTS. AOAC; HORWITZ, W. (ed). Official methods of analysis. 17. ed. Washington D.C: AOAC, 2000. v. 2, p. 20-24.

ASSOCIATION OF OFFICIAL ANALYTICAL CHEMISTS. AOAC; HORWITZ, W. (ed). Official Methods of Analysis. 15. ed. Washington D.C: AOAC, 2005.

BENDER, F.E.; DOIGLAS, L.W.; KRAMER, A. Statistical methods for food and agriculture. Westport: Avi Publishing Company, Inc., 1982. p. 91-94.

BERNDTSON, W.E. A simple, rapid and reliable method for selecting or assessing the number of replicates for animal experiments. J. Anim. Sci., v.69, n.1, p.67-76, 1991.

BERTI, C.; RISO, P.; BRUSAMOLINO, A.; PORRINI, M. Effect on appetite control of minor cereal and pseudocereal products. Brit. J. Nutr., v.94, n.5, p.850-858, 2005. 
BHARGAVA, A.; SHUKLA, S.; OHRI, D. Chenopodium quinoa - An Indian perspective. Ind. Crops Prod., v.23, n.1, p.73-87, 2006.

BLIGH, E.G., DYER, W.J. A rapid method of total lipid extraction and purification. Can. J. Biochem. Physiol., v.37, n.8, p.911-917, 1959.

BRASIL. Resolução n. 18, de 30 de abril de 1999. Aprova o Regulamento Técnico que estabelece as diretrizes básicas para análise e comprovação de propriedades funcionais e ou de saúde alegadas em rotulagem de alimentos. Diário Oficial da União, Brasília. Disponível em: <http://portal.anvisa.gov.br/wps/ wcm/connect/815ada0047458a7293e3d73fbc4c6735/ RESOLUCAO_18_1999.pdf?MOD=AJPERES $>$. Acesso em: 08 out. 2014.

BRASIL. Resolução n. 360, de 23 de dezembro de 2003. Aprova regulamento técnico sobre rotulagem nutricional de alimentos embalados, tornando obrigatória a rotulagem nutricional. Diário Oficial da União, Brasília. Disponível em: <http://portal.anvisa.gov.br/wps/ wcm/connect/ec3966804ac02cf1962abfa337abae9d/ Resolucao_RDC_n_360de_23_de_dezembro_de_2003. pdf?MOD=AJPERES $>$. Acesso em: 08 out. 2014.

BORGES, J.T.S.; VIDIGAL, J.G.; SILVA, N.A.S.; PIROZI, M.R.; PAULA, C.D. Caracterização físico-química e sensorial de pão de forma contendo farinha mista de trigo e quinoa. Rev. Bras. Prod. Agroind., v.15, n.3, p.305 -319, 2013.

FIRESTONE, D. (Ed.) Official methods and recommended practices of the American Oil Chemists Society. 5. ed. Champaign: AOCS, 1998. 1300p.

FRIEDEWALD, W.T.; LEVY, R.I.; FREDRICKSON, D.S. Estimation of the concentration of low-density lipoprotein cholesterol in plasma, without use of the preparative ultracentrifuge. Clin. Chem., v.18, n.6, p.499-502, 1972.

GORINSTEIN, S.; VARGAS, O.J.M.; JARAMILLO, N.O.; SALAS, I.A.; AYALA, A.L.M.; ARANCIBIA-AVILA, P.; TOLEDO, F.; KATRICH, E.; TRAKHTENBERG, S. The total polyphenols and the antioxidant potentials of some selected cereals and pseudocereals. Eur. Food Res. Tech., v.225, n.3/4, p.321-328, 2007.
HARTMAN, L.; LAGO, R.C.A. Rapid preparation of fatty acid methyl esters from lipids. Lab. Practice, v.22, n.8, p.475-476, 1973.

HOLLAND, B.; WELCH, A.A.; UNWIN, I.D.; BUSS, D.H.; PAUL, A.A.; SOUTHGATE, D.A.T. McCance and Widdowson's the composition of foods. 5. ed. Cambridge: Royal Society of Chemistry, 1991. 462p.

MANCINI-FILHO, J. Alimentos funcionais nas doenças cardiovasculares. In: COSTA, N.M.B.; ROSA, C.O.B.(Eds.) Alimentos funcionais. Viçosa: Folha de Viçosa, 2006. cap.5, p.99-114.

MITHILA, M.V.; KHANUM, F. Effectual comparison of quinoa and amaranth supplemented diets in controlling appetite; a biochemical study in rats. J. Food Sci. Tech., v. 52, n.10, p. 6735-6741, 2015.

MORETTO, E.; FETT, R. Tecnologia de óleos e gorduras vegetais: na indústria de alimentos. São Paulo: Livraria Varela, 1998. 150p.

NASIR, M.A.; PASHA, I.; BUTT, M.S.; NAWAZ, H. Biochemical chacarterization of quinoa with special reference to its protein quality. Pak. J. Agric. Sci., v.52, n.3, p.731-737, 2015.

OLIVARES, S.; ZACARIAS, I. Recomendaciones de lípidos y ácidos grasos. Cómo aplicarlas en la práctica. Diaeta, v.36, n.39, p.35-43, 1997.

POINOT, P.; ARVISENET, G.; GRUA-PRIOL, J.; FILLONNEAU, C.; LE-BAIL, A.; PROST, C. Influence of inulin on bread: Kinetics and physico-chemical indicators of the formation of volatile compounds during baking. Food Chem., v.119, n.4, p.1474-1484, 2010.

POJIC, M.; DAPC, T.; HADNADEV, T.D.; HADNADEV, M.; RAKITA, S.; BRLEK TEA. Bread supplementation with hemp seed cake: a by-product of hemp oil processing. $J$. Food Qual., v.38, p.431-440, 2015

REPO-CARRASCO, R.; ESPINOZA C.; JACOBSEN, S.E. Nutritional value and use of the Andean crops quinoa (Chenopodium quinoa) and kaniwa (Chenopodium pallidicaule). Food Rev. Int., v.19, n.1/2, p.179-189, 2003. 
SANTOS, K.M.O.; AQUINO, R.C. Grupos dos óleos e gordura. In: PHILIPPI, S.T.(Ed.) Pirâmide dos Alimentos: fundamentos básicos da nutrição. Barueri: Manole, 2008. cap.7, p.241-292.

SGARBIERI, V.C. Alimentação e nutrição: fator de saúde e desenvolvimento. Campinas: Ed. da UNICAMP, 1987. 387 p.

ŠKRBIC, B.; MILOVAC, S.; DODIG, D.; FILIPCEV, B. Effects of hull-less barley flour and flakes on bread nutritional composition and sensory properties. Food Chem., v.115, n.3, p.982-988, 2009.

TAKAO, T,; WATANABE, N.; YUHARA, K.; ITOH, S.; SUDA, S.; TSURUOKA, Y.; NAKATSUGAWA, K.; KONISHI, Y. Hypocholesterolemic effect of protein isolated from quinoa (Chenopodium quinoa Willd.) seeds. Food Sci. Tech. Res., v.11, n.2, p.161-167, 2005.
TIWARI, U.; CUMMINS, E. Nutritional importance and effect of processing on tocols in cereals. Trends Food Sci. Technol., v.20, n.11/12, p.511-520, 2009.

VALENZUELA, A.; SANHUEZA, J.; NIETO, S. Oxidos del colesterol (oxisteroles) em alimentos: factores que condicionan su formación y sus efectos biológicos. Aceites y Grasas, v.9, n.11, p.271-278, 1998.

WILLIAMS, S. R. Fundamentos de nutrição e dietoterapia. 6.ed. Porto Alegre: Artemed Editora, 1997. 664p.

Received for publication on $27^{\text {th }}$ October 2015 Accepted for publication on $02^{\text {nd }}$ May 2016 